\title{
HOLISTIC APPROACH TO RISK MANAGEMENT IN CREATIVE SECTOR ORGANIZATIONS ${ }^{1}$
}

\section{HOLISTYCZNE PODEJŚCIE DO ZARZĄDZANIA RYZYKIEM W ORGANIZACJACH SEKTORA KREATYWNEGO}

\author{
JACEK WOŹNIAK \\ jacekj.wozniak@wat.edu.pl \\ MILITARY UNIVERSITY OF TECHNOLOGY \\ FACULTY OF CYBERNETICS \\ WIOLETTA WEREDA \\ weredawioletta@tlen.pl \\ MILITARY UNIVERSITY OF TECHNOLOGY \\ FACULTY OF CYBERNETICS
}

\begin{abstract}
In the article, there is considered an issue of holistic view at risk category in organizations of the creative sector. This article presents specification and analysis of holistic conditions of risk management for organizations from this sector - with particular emphasis on identification of risk factors. In considerations, there is also a reference to application of cognitive maps and business models in a holistic risk management in organizations of the creative sector.
\end{abstract}

Keywords: management, risk, creative sector, business model, cognitive map, network thinking.

Streszczenie: $\mathrm{W}$ artykule podejmowana jest problematyka holistycznego spojrzenia na kategorię ryzyka w organizacjach sektora kreatywnego. Przedstawiona jest specyfikacja i analiza holistycznych uwarunkowań zarządzania ryzykiem w organizacjach z tego sektora - ze szczególnym uwzględnieniem identyfikacji czynników ryzyka. W rozważaniach następuje odwołanie do zastosowania map kognitywnych i modeli biznesowych w holistycznym zarządzaniu ryzykiem w organizacjach sektora kreatywnego.

Słowa kluczowe: zarządzanie, ryzyko, sektor kreatywny, model biznesowy, mapa kognitywna, myślenie sieciowe.

\section{Introduction}

Creative sector organizations operate under conditions of high volatility of global and local environment. The dynamism of environment's conditions is also determined by a peculiarity of a creative sector that: (1) is focused on continuous meeting the needs of customers and creation of their potential needs, (2) is concentrated at shaping elements of broadly understood culture, as well as (3) is internally

\footnotetext{
1 The article is financed from the public science funds as a research project No. RMN 812/2016 (Faculty of
} Cybernetics, Military University of Technology in Warsaw). 
diversed. Therefore, managers and operational staff should design and implement risk management processes in the organization. Not in any type of organization (also in the creative sector) possible and reasonable (e.g. in terms of costs) is to implement a complete and comprehensive system of risk management - it is so e.g. in micro organizations that are operating in the area of design and architecture. However, in organizations of this sector it is worth to implement at least elements of the risk management system. Helpful, in this case, is a holistic approach, that can be used in both complex and simple organizational systems.

The theoretical objective of this article is to specify conditions and mechanisms for holistic risk management in creative sector organizations, while the utilitarian objective is to present the basic tools for a holistic identification and risk analysis, i.e. the patterns of business models and cognitive maps. The scope of the study concerns an issue of holistic identification of risk factors (both the opportunities and threats factors), determining an impact of these factors on the organization and taking actions against them. The research problem is presented as follows: which are the basic conditions of risk management in the creative sector organizations. A leading research method is a critical literature analysis, supplemented by the methods of deduction and synthesis.

The article consists of three parts, which in turn are related to: (1) a presentation of a holistic action as a method of risk management, (2) a holistic view of the creative sector from the perspective of glocalization processes and (3) a holistic approach to risk management in the creative sector using the patterns of business models and cognitive maps.

\section{Holism as a method of risk management}

Holism, as one of the approaches to the systemic management of organizations is not an achievement of a modern science. Currently, it is observed as a kind of "renaissance" of holistic thinking and activities (see [in:] Mulej et al., 2004, p. 49 et seq.), as it was established much earlier - in fact, it dates back to ancient times. Aristotle is considered as the "father" of the system research and declared that "the whole is more than the sum of the parts" (Sienkiewicz, 1988, p. 46). Going back to the less changing days, it should be noted that the author of the foundations of the general systems theory (as a source of a holistic approach), was an Austrian biologist and philosopher Ludwig von Bertalanffy. In the 1920s. of the 20th century he proved that living organisms, despite the differences in external behavior, have an internal similarities (Borodzicz, 2005, p. 22). First references to the socio-technical grasp of the systems theory in an area of management science dates back to the pioneering work of the Tavistock Institute, referring to the organizational changes in the British coal industry (Borodzicz, 2005, pp. 22-23). This theory has initiated the overall system look at the processes / relationships and objects (including e.g. business organizations). 
Holism assumes an overall look, i.e. does not require the "breaking" of objects on the basic elements to explore and understand them, as well as intervene in their structure. It is inversely - holism is focused on a general level and encourages managers to pay attention if individual elements are linked correctly and whether are flows between them oriented at implementation of objectives (Jackson, 2006, p. 650). Moreover, the holistic approach encourages to use interdisciplinary analogies, as well as expose both the structure of objects and processes, giving rise to learning mechanisms - what in today's organizations is particularly important (also from the risk management point of view). Holistic perspective in the management of organizations, on the one hand allows solving strategic and complex-natured problems and on the other hand supporting operational, technical activities of narrow content. In this way, managers are able to make "fight" with the complexity and instability of an ambient (Jackson, 2006, pp. 648-649). V. Potocan and M. Mulej (2009, pp. 94-96) indicate, that holistic thinking is primarily characterized by: (1) emergency, (2) presence of an attractor, i.e. the point or area to which aims at the whole system, (3) complexity and complicating (4) openness, (5) occurrence of internal relationships and synergies, (6) a wide and comprehensive analytical perspective, and (7) networking structure and mutual interactions.

A kind of reflection of the holism in practical operation is network thinking, was launched at the University of St. Gallen in Switzerland. This method refers to the cause and effect schema, that is to identify sources and consequences of specific events in a system / organization. It supports a holistic decision-making problems' solving in organizations - in fact, it enables identification, defining and solving a problem situation (e.g. a "bottleneck"), also in relation to the previously resolved issues (it is created a so-called knowledge base) (based on: Rosi, Mulej, 2006, pp. 1166-1167).

A holistic approach, mainly due to usability and functionality in solving complex and heterogeneous decision-making processes, can be thought of as a method of risk management in organizations of various types, including a creative sector. Thus, it is not a surprise that elements of a holistic thinking are included in the standards and procedures of risk management. As examples can be used e.g.: $\mathrm{COSO}^{2}$ Internal Control Integrated Framework (ICIF) (see [in:] COSO, 2013), COSO Enterprise Risk Management (ERM) (see [in:] COSO, 2004) and ISO 31000:2009 (see [in:] ISO, 2009). These documents strongly allude to the system and process approach to managing organizations (based on: McNally, 2015, pp. 28-29), with an emphasis on supporting implementation of various time horizons' objectives. It should also be noted that these objectives are closely linked with implementation of the control function - what additionally underlines the opportunity of using these solutions in the field of risk management.

\footnotetext{
2 The Committee of Sponsoring Organizations of the Treadway Commission.
} 
In a holistic approach, there is a crucial role played in an environment of an organization, which is a situational context for decision-making processes (indicates that at least ISO 31000:2009). P. Zaskórski (2014, p. 9 et seq.) stresses that enterprise's environment should be included in the full cycle of risk management. Organizations of various types (regardless e.g. of activity's profile and size criteria) operate in the environment that is a source of both opportunities and threats. Therefore, risk management processes should be skillfully integrated with elements of the nearer and further environment (see more [in:] Bharathy, McShane, 2014, pp. 38-45). To summarize the above issues, a reference should be made to the evolution of risk management models proposed by U. Krysiak and Z. Krysiak (2013, p. 52 et seq.) indicating that the eighth level of that "evolution" is called a holistic risk management, that comes down (in simplification) to sharing risk between constituent parts of the organization, while its integration. This allows e.g. an internal transfer of risk during a simultaneous monitoring a state of an entire organization.

\section{Glocalization as a basis for a holistic perception of a creative sector}

Changes in functioning of national economies observed from the mega economic perspective take effect of two parallel trends: (1) homogenization of cultural and socio-economic layers of life of both individual people and whole societies (i.e. globalization) and (2) the pursuit of individual countries or regions to customization, as well as creation and promotion their own values (i.e. localization). As B. Pasamonik (2016, p. 133) indicates, globalization and localization, despite the fact that are opposite processes, cannot be seen separately - because they complement each other. The relationship of globalization-localization is doublesided. A coupling mechanism of globalization and the localization is glocalization ${ }^{3}$. In addition, B. Pasamonik evokes the phrase of British sociologist R. Robertson (original source: Robertson, 1995), that "the only sensible perspective of analysis and evaluation of globalization is the bottom-up perspective - i.e. the local one" (Pasamonik, 2016, p. 133). It is also worth to bring up the following observations of B. Pasamonik (2016, p. 133), that "the new localism, though, is preordained to a global context, opposes its particular values to the unifying influence of globalization. Localism / particularism is a protest against universalizing and unifying tendencies of globalization".

Therefore, at this canvas, a perception of socio-economic and cultural life of people seems to be reasonable. Today, people of different cultures tend to turn their own ethnic elements into their activities. Broad-based activities of this

\footnotetext{
Glocalization can be defined as transforming global patterns and their impact on the peculiarities of particular localizations. In other words - what is "global", becomes "local" and defines changes to functioning of "local" systems. It is a "local dimension of globalization" (Kuciński, 2011, p. 10). The concept of glocalization in the economic literature further develops K. Kuciński (see e.g. [in:] Kuciński, 2011; Kuciński, 2014).
} 
type can be observed e.g. in branches of: cinematography, fine arts, architecture, theatre, industrial design, literature, music, and so on. This has an impact also on the sphere of economic life, where specific local rules, e.g. of goods' circulation, working time, forms of remuneration for work, how to setting up and running a business, etc., are considered as the most important. It is crucial that along with deepening of globalization processes, local business conditions are growing more significant (i.e. first and second degree ambient) (based on: Kuciński, 2011, p. 9). For example, enterprises look to global business leaders, but its own offer is adapted to the needs of local customers. Similar phenomenon occurs concerning global leaders (corporations), who, in many cases, move away from global strategies (for a homogeneous customer), and shape international strategies (differentiating customers in terms of culture, level of affluence, habits and fashions, etc. Enterprises, whether local or global, through their business, shape their surroundings (i.e. a local sphere). A key category seems to be here a customer with declared values, and a basic process - a proper customer segmentation on a global scale, to collate information on local trends.

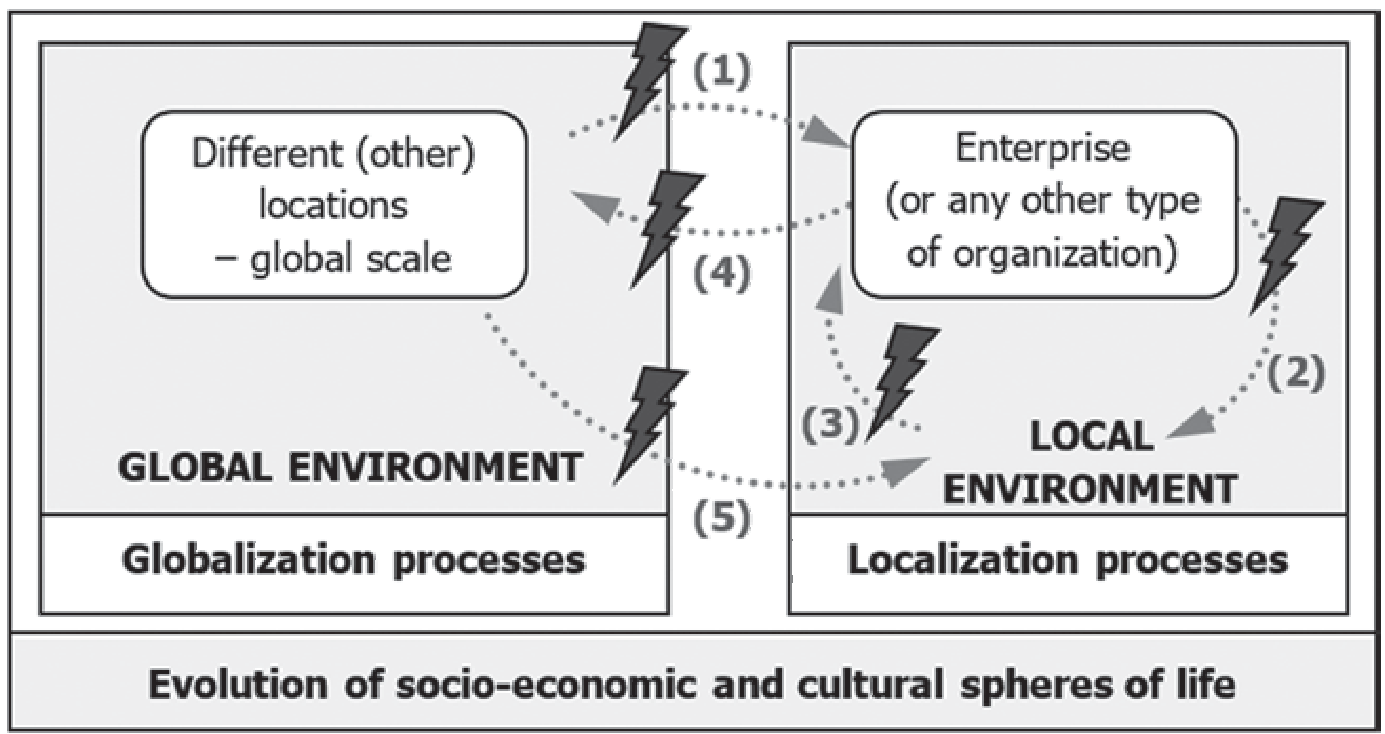

Basic relationships:

(1) providing resources (also knowledge), patterns of action, etc. by a global culture

(2) forming a local environment by an enterprise (organization), e.g. customer behavior patterns, fashions, standards, cultural patterns, ethical standards, etc.

(3) an impact of local conditions on enterprise's (organization's) functioning

(4) powering a global culture by values created locally, e.g. enrichment of a global culture by new trends and local patterns in a given culture

(5) an impact of global conditions on a local environment, e.g. potential buyers, institutional environment, etc.

- areas of an emergence of risk 
These connections between local and global perspectives are conducive to shape and develop the creative sector. This type of interactions result in changes e.g. in socio-economic and cultural areas. The operation of enterprises (and other types of organizations) in the global economy affects the behavior of their co-participants and competitors in the local scale. An enterprise which uses information and communication technologies, can interact with global partners (e.g. in frameworks of offshoring), creating virtual structures. This gives an enterprise access to global resources - not only material ones, but also knowledge, know-how, etc.

Relationships between processes of globalization and localization (Fig. 1) can be considered in terms of one of the key determinants of shaping and developing the creative sector. In general, it can be concluded that the creative sector is a kind of attempt to match global standards and patterns to peculiarity of a local community. The creative sector is some kind of answer to local needs of globalizing societies as well as one of the paths to create new, local values - which combine socio-economic and cultural conditions of life.

\section{Holistic approach to risk management in the creative sector}

A holistic approach can be the starting point for identification primary risk factors in activities of entities forming the creative sector. It indicates basic relationships between the creative sector and an environment, e.g. an institutional one, without which creative sector organizations are not able to function correctly - especially in activities based on culture, where organizations without an external financial support are not able to maintain the continuity of process. Figure 2 presents three basic relationships between organizations from the creative sector and an environment, which can be sources of the following risk factors:

- relationship (1) - driving up prices by organizations carrying out applied activities, what could results in reduction in demand for offered goods; lack of interest by the side of R\&D organizations (knowledge sharing, joint development of new solutions); unqualified personnel resulting in reduction of applied goods' quality; no matching between an offer of applied goods, and needs or requirements of key market segments; lack of loyalty of customers, etc.,

- relationship (2) - lack of interest in the offer of cultural goods from key audiences; expenses exceed the approved budget; lack of cooperation by the side of entities creating innovations and providing specific technologies, etc.,

- relationship (3) - the use of inappropriate cultural patterns; lack of interest by the side of financing entities, etc.

Understanding a peculiarity of risk management in the creative sector in accordance with a holistic approach (as a reflection of relationships shown in figure 2) also requires a reference to an issue of business models' construction of that 
can be implemented in this type of organizations. In this situation, the business model schema developed by M.W. Johnson, C.M. Christensen and H. Kagermann (2009, pp. 155-165) ${ }^{4}$, can be helpful whose components are: (1) value proposition for a customer, (2) profit formula, (3) key resources, and (4) key processes.

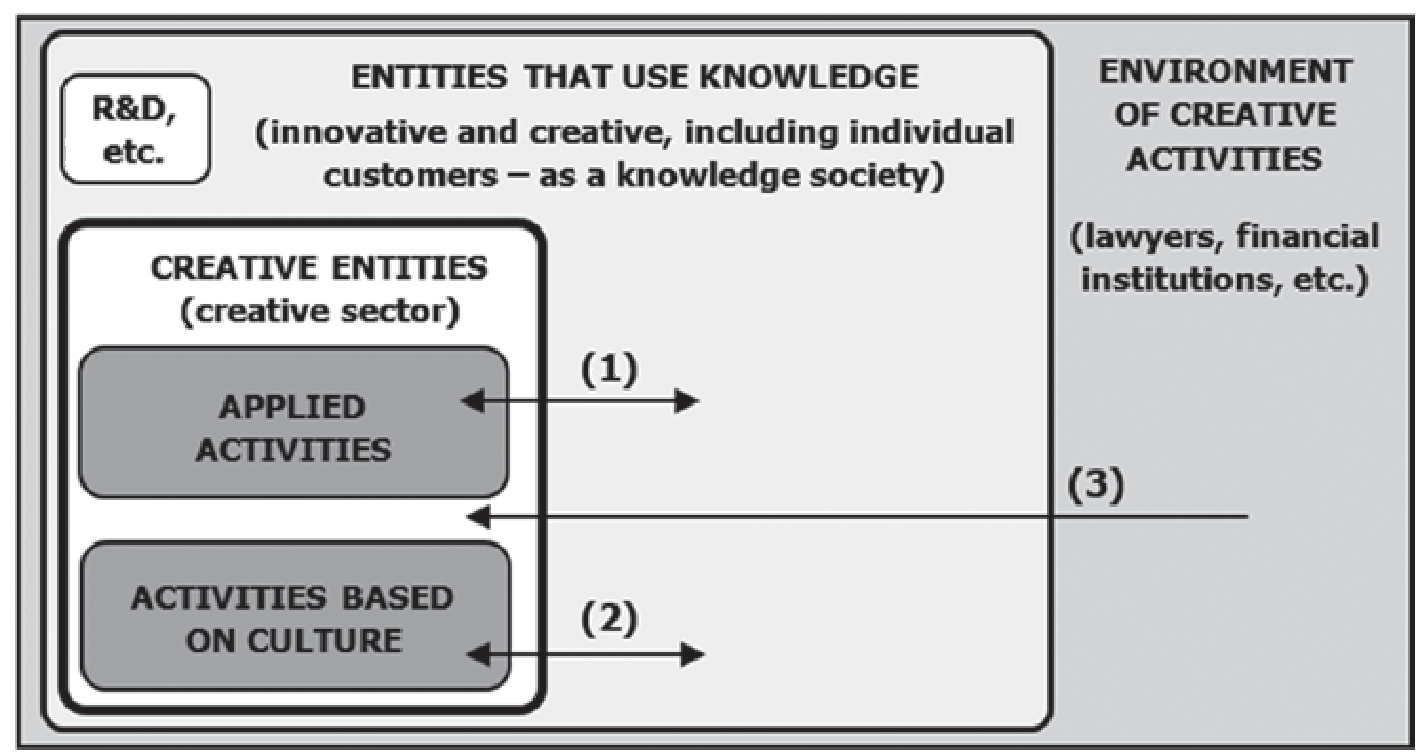

Fig. 2. A holistic perspective of the creative sector - in the context of risk factors' identification Source: own work based on: Grochowski et al., 2012, p. 16

Making an analysis of a content of table 1, it should be noticed that in each of business model patterns for four classes of activities in the creative sector there can be identified both negative risk factors (i.e. threats factors) and positive risk factors (i.e. opportunities factors). This is due to the fact that certain factors - occurring or within an organization, or in its surroundings - can be a source of losses or benefits (mainly in a financial meaning). Taking an action, managers or employees of lower levels expect a specific effect, e.g. a profit. At the same time, they are aware of a probability of threats. This approach to risk management is a reflection of a neutral perception of risk category and is treated as a "contemporary" activity (Kasiewicz, Rogowski, 2006, p. 34).

This approach is desirable especially in creative sector organizations, because their permanent property is active shaping an environment, characterized by a propensity to take risk, a tolerance of specific threats and openness to change. Employees of the creative sector, stimulating an environment (also internal resources), expect concrete results, measured e.g. by a degree of customers' satisfaction and development of their own industry / branch, strengthening a market position of unique products or services, a range of their promotional campaign, a number of participants in cultural events or an amount of received budget dotation and level of generated revenues. However, the fact should be remembered that creative sector organizations manage risk to protect their

\footnotetext{
A choice made [by:] Dziurski, 2016, pp. 85-86.
} 
business, e.g. in terms of maintaining a continuity of processes. Therefore, not only prone to risk (manifested e.g. in creating and consuming opportunity factors), but also elimination or neutralization of threat factors can have an importance in building organization's potential.

A construction of business models expose such elements as: value for customers, mechanisms of profits' creation, sources and structure of resources as well as specification of basic processes, it is a kind of reflection of a holistic approach to risk management (see tab. 1). It is a derivative of the fact, that e.g.:

- elements of business models correspond to an analysis of both internal capabilities of an organization as well as ambient conditions (Dziurski, 2016, p. 87) - so they are a source of identification of relationships between an organization and its environment, e.g. in an issue of obtaining, allocation and relocation of resources, and thus also identification of risk factors - as derivatives of these relationships,

- these elements of business models can be laid in a comprehensive, complete and multi-dimensional value chain whose key elements are: customers, value drivers and basic processes (thus, given risk factors can be cumulated in a whole value chain),

- such approach integrates human (social), economic, organizational and technical planes of value's creation - none of mentioned above elements are discriminated and identified risk factors are multifaceted,

- identified four components of business models for a creative sector are mutually complemented and penetrated - e.g.: key resources determine a cost structure while a specification of basic processes determines a need for resources and possible to achieve value for a customer; this allows to observe partially an influence of some risk factors on the other (basically in a simplified form), identifying "bottlenecks",

- a specificity of four basic elements of business models may be shaped differently in various classes of creative sector organizations; thus, individual types of organizations can be analyzed in a wider context of a whole sector, helping to identify differences and similarities in terms of requirements, capacities and limitations of certain types of organizations in the area of risk management; this allows to claim whether risk management patterns developed for a one class of organizations in a creative sector can be moved (under certain conditions) to another class of organizations. 
Tab. 1. Patterns of business models in the creative sector (using a classification of creative activities by NESTA) perspective of a holistic identification of risk factors (opportunities and threats factors)

\begin{tabular}{|c|c|c|c|}
\hline \multicolumn{4}{|c|}{ COMPONENTS OF BUSINESS MODELS = AREAS OF RISK FACTORS' IDENTIFICATION } \\
\hline Value for customers & Profit formula & Key resources & Key processes \\
\hline \multicolumn{4}{|c|}{ PATTERN No. I: Creative Service Providers } \\
\hline \multicolumn{4}{|c|}{ Examples: advertising agencies, architectural and design offices } \\
\hline $\begin{array}{l}\text { Description: provisioning } \\
\text { services covered by protection of } \\
\text { authorship works, individualization } \\
\text { and inability of imitation of } \\
\text { services, value added is dedicated } \\
\text { to a specific customer, usually } \\
\text { a service is disposable in a given } \\
\text { form (i.e. a business project) }\end{array}$ & $\begin{array}{l}\text { Description: revenues: service's } \\
\text { implementation fee; costs: } \\
\text { carrying out a service, costs of } \\
\text { complaints and corrections, costs } \\
\text { related to service resignation by } \\
\text { a customer (at a designing stage), } \\
\text { costs associated with providing } \\
\text { discounts to customers }\end{array}$ & $\begin{array}{l}\text { Description: knowledge and } \\
\text { skills of professionals / designers, } \\
\text { relationships in a professional / } \\
\text { work environment, e.g. with } \\
\text { subcontractors and competitors, } \\
\text { reputation, strong brand, } \\
\text { efficient management system } \\
\text { in an organization }\end{array}$ & $\begin{array}{l}\text { Description: creation and } \\
\text { designing, sales, establishing } \\
\text { lasting relationships with } \\
\text { customers, promotion of services, } \\
\text { market analysis }\end{array}$ \\
\hline $\begin{array}{l}\text { Examples of risk factors: } \\
\text { organization's focus on a profit and } \\
\text { not values for customers, e.g. by } \\
\text { undercutting a quality of projects } \\
\text { and imitating existing solutions } \\
\text { on a market (offered to other } \\
\text { customers) }\end{array}$ & $\begin{array}{l}\text { Examples of risk factors: loss of } \\
\text { incomes determined by customers' } \\
\text { frauds, growth of hidden costs } \\
\text { (e.g. not monitored and included } \\
\text { in a price of services), opening } \\
\text { of businesses on new market } \\
\text { segments, horizontal diversification } \\
\text { of activities, implementation of } \\
\text { unprofitable processes, lack of } \\
\text { customer loyalty }\end{array}$ & $\begin{array}{l}\text { Examples of risk factors: } \\
\text { theft of intellectual property } \\
\text { (ideas, designs, finished } \\
\text { projects), lack of a systematic } \\
\text { improvement of competences } \\
\text { of specialists / designers, volatile } \\
\text { relationships with co-participants, } \\
\text { decline in a value of a brand, } \\
\text { functioning of a grey market }\end{array}$ & $\begin{array}{l}\text { Examples of risk factors: } \\
\text { mismatch between structure } \\
\text { of processes and needs of a market, } \\
\text { appearance of faults in design } \\
\text { processes, lack of a permanent } \\
\text { communication with customers, } \\
\text { broadening a scope and complexity } \\
\text { of design processes }\end{array}$ \\
\hline
\end{tabular}


Tab. 1. Patterns of business models in the creative sector (using a classification of creative activities by NESTA) - continuation

\begin{tabular}{|c|c|c|c|}
\hline \multicolumn{4}{|c|}{ COMPONENTS OF BUSINESS MODELS = AREAS OF RISK FACTORS' IDENTIFICATION } \\
\hline Value for customers & Profit formula & Key resources & Key processes \\
\hline \multicolumn{4}{|c|}{ PATTERN No. II: Creative Content Producers } \\
\hline \multicolumn{4}{|c|}{ Examples: producers of movies, music, software and computer games } \\
\hline $\begin{array}{l}\text { Description: production of } \\
\text { a content that is provided to a wide } \\
\text { audience, content is covered } \\
\text { by intellectual property protection }\end{array}$ & $\begin{array}{l}\text { Description: revenues: content } \\
\text { sales, advertising, content } \\
\text { licensing; costs: content creation, } \\
\text { marketing, lack of customers' } \\
\text { interests (misguided production), } \\
\text { costs of modifications suggested } \\
\text { by customers }\end{array}$ & $\begin{array}{l}\text { Description: financial resources, } \\
\text { machines and equipment, } \\
\text { knowledge and skills, relationships } \\
\text { with customers (e.g. a systematic } \\
\text { market analysis), reputation, } \\
\text { a strong brand, efficient } \\
\text { management system }\end{array}$ & $\begin{array}{l}\text { Description: creation and } \\
\text { designing, manufacturing, } \\
\text { marketing (e.g. creation of lasting } \\
\text { relationships with customers), } \\
\text { strategic planning (in terms of } \\
\text { organization's development through } \\
\text { creating future customers' needs) }\end{array}$ \\
\hline $\begin{array}{l}\text { Examples of risk factors: } \\
\text { organization's focus on a profit } \\
\text { and not values for customers, } \\
\text { offering overly standardized } \\
\text { content and products } \\
\text { (no penetration of specific, } \\
\text { homogeneous market segments) }\end{array}$ & $\begin{array}{l}\text { Examples of risk factors: } \\
\text { opening a business in new } \\
\text { market segments, horizontal } \\
\text { diversification of activities, } \\
\text { obtaining expensive and rare } \\
\text { resources }\end{array}$ & $\begin{array}{l}\text { Examples of risk factors: limited } \\
\text { access to financing sources, } \\
\text { searching for alternative forms of } \\
\text { financing, lack of quality control } \\
\text { system in an organization }\end{array}$ & $\begin{array}{l}\text { Examples of risk factors: } \\
\text { lack of identification of future } \\
\text { needs of customers, too high } \\
\text { complexity of design processes, } \\
\text { designing and implementation } \\
\text { of too capital-intensive processes }\end{array}$ \\
\hline \multicolumn{4}{|c|}{ PATTERN No. III: Creative Experience Providers } \\
\hline \multicolumn{4}{|c|}{ Examples: theatrical producers, organizers of concerts and festivals } \\
\hline $\begin{array}{l}\text { Description: offering services that } \\
\text { take a form of experience received } \\
\text { by customers only once in a given } \\
\text { form (at the time of processes } \\
\text { providing) }\end{array}$ & $\begin{array}{l}\text { Description: revenues: service } \\
\text { enjoyment fee, sponsoring } \\
\text { of cultural events; costs: } \\
\text { preparation of processes / services, } \\
\text { marketing, access to resources } \\
\text { and skills of implementers } \\
\text { of processes / artists }\end{array}$ & $\begin{array}{l}\text { Description: financial resources, } \\
\text { knowledge and skills, relationships } \\
\text { with customers and services' } \\
\text { contractors, e.g. artists, reputation } \\
\text { of event's organizer and involved } \\
\text { artists, efficient management system } \\
\text { (connected e.g. with organization } \\
\text { and functioning of a project office) }\end{array}$ & $\begin{array}{l}\text { Description: creating, designing, } \\
\text { organization and production } \\
\text { of processes / cultural events, } \\
\text { analysis of a market and customer } \\
\text { needs (also the potential ones), } \\
\text { searching for sources of activities' } \\
\text { financing }\end{array}$ \\
\hline
\end{tabular}




\begin{tabular}{|c|c|c|c|}
\hline \multicolumn{4}{|c|}{ COMPONENTS OF BUSINESS MODELS = AREAS OF RISK FACTORS' IDENTIFICATION } \\
\hline Value for customers & Profit formula & Key resources & Key processes \\
\hline $\begin{array}{l}\text { Examples of risk factors: lack } \\
\text { of match between a theme of } \\
\text { a service and current needs of } \\
\text { a public / audiences, too low } \\
\text { quality of services, quality does } \\
\text { not respond to generally accepted } \\
\text { standards of art, creation of } \\
\text { new customers' needs, new } \\
\text { trends in the art and luxury } \\
\text { services / goods }\end{array}$ & $\begin{array}{l}\text { Examples of risk factors: lack of } \\
\text { interest in events / cultural services, } \\
\text { obtaining too expensive resources } \\
\text { in the form of artists' skills, lack } \\
\text { of financial liquidity at a stage of } \\
\text { preparation of cultural events }\end{array}$ & $\begin{array}{l}\text { Examples of risk factors: limited } \\
\text { access to funding sources, } \\
\text { e.g. on a basis of sponsorship, } \\
\text { volatile relationships with co- } \\
\text { participants / artists, outsourcing } \\
\text { determined by reducing costs } \\
\text { of events' organization, loss } \\
\text { of an access to rare resources } \\
\text { during an implementation of } \\
\text { processes / cultural events }\end{array}$ & $\begin{array}{l}\text { Examples of risk factors: } \\
\text { designing and implementation } \\
\text { of too capital-intensive processes, } \\
\text { highly developed system of } \\
\text { a financial control, widening } \\
\text { of a scope and complexity of } \\
\text { processes without any support } \\
\text { in a market analysis }\end{array}$ \\
\hline \multicolumn{4}{|c|}{ PATTERN No. IV: Creative Originals Producers } \\
\hline \multicolumn{4}{|c|}{ Examples: makers of handicrafts, fashion designers } \\
\hline $\begin{array}{l}\text { Description: production } \\
\text { of unique, culturally-natured, } \\
\text { and dedicated mainly to a single } \\
\text { customer goods, production } \\
\text { strongly related to competences } \\
\text { of process' implementer }\end{array}$ & $\begin{array}{l}\text { Description: revenues: sales; } \\
\text { costs: fixed costs, products' } \\
\text { producing, marketing (branding), } \\
\text { unprofitable investments in } \\
\text { a development of an organization } \\
\text { (own brand) }\end{array}$ & $\begin{array}{l}\text { Description: machines and } \\
\text { equipment, knowledge, skills and } \\
\text { reputation of process' implementer, } \\
\text { a strong brand, relationships with } \\
\text { co-participants and customers }\end{array}$ & $\begin{array}{l}\text { Description: creation and } \\
\text { designing, manufacturing, sales, } \\
\text { marketing (e.g. market analysis, } \\
\text { promotion, pricing policy) }\end{array}$ \\
\hline $\begin{array}{l}\text { Examples of risk factors: } \\
\text { undercutting a quality of } \\
\text { projects, lack of a match } \\
\text { to needs of customers (lack of } \\
\text { communication), meeting internal } \\
\text { needs of a designer / craftsman, } \\
\text { and not customers }\end{array}$ & $\begin{array}{l}\text { Examples of risk factors: offering } \\
\text { too high price for products (lack } \\
\text { of demand), too capital- and time- } \\
\text { intensive brand promotion, lack of } \\
\text { financial liquidity, a need to make } \\
\text { corrections (hidden costs) }\end{array}$ & $\begin{array}{l}\text { Examples of risk factors: too } \\
\text { enlarged and / or obsolete } \\
\text { machinery, lack of experience of } \\
\text { a designer / craftsman, creation } \\
\text { of strong relationships with key } \\
\text { customers }\end{array}$ & $\begin{array}{l}\text { Examples of risk factors: } \\
\text { development of a customer } \\
\text { relationship management } \\
\text { system, standardization of design } \\
\text { processes, mechanization of } \\
\text { manufacturing processes, a use of } \\
\text { information and communication } \\
\text { technologies in marketing }\end{array}$ \\
\hline
\end{tabular}

Source: own work based on: Dziurski, 2016, p. 86 
A specific presentation of a holistic approach to risk management in creative sector organizations presented in table 1 , is the elaboration of cognitive maps, which can be regarded as a basic tool for identification of relationships between various risk factors, including opportunities and threats factors. Cognitive maps also permit indication of strength of an impact of individual factors on each other (positive or negative impact of varying strength) (Godlewska-Majkowska, 2014, pp. 42-45). In risk management, a particular importance is given to identification as many factors as it is possible, which may be either a source of threats or opportunities. In a business practice, also in a creative sector, risk factors are not "autonomous" and appear separately from an organizational system and environment. An omission of any of the factors (or the whole group of factors) may result in errors in decision-making processes (based on: Zaskórski, 2012, pp. 150-155). This may be a source of incorrect processes of risk transfer, risk factors' avoiding, minimizing a negative impact of risk factors, or achieving benefits in reference to processes of creating opportunities. Cognitive maps allow to identify not only a direct impact of risk factors but also an indirect impact (Godlewska-Majkowska, 2014, p. 42). Thus, cognitive maps can be regarded as a tool of a network thinking (see e.g. [in:] Piekarczyk, Zimniewicz, 2010, p. 11 et seq.). In addition, it is a flexible tool, because it is tailored to both quantitative (econometric) and qualitative analysis (Axelrod, 1976; Yastrebov, Słoń, 2011, [by:] Godlewska-Majkowska, 2014, p. 43).

In figure 3 there is presented the example of a cognitive map an illustration of a holistic approach to identify risk factors and dependencies between these factors. This map is elaborated on a basis of an individual in-depth interview (IDI) carried out with an owner of a designing organization that develops furniture and interior arrangement ${ }^{5}$. On a basis of a preliminary analysis of dependencies on this cognitive map, it can be noticed that basic actions in the field of risk management (targeted e.g. to increase a level of competitiveness of the company) should be complexed and multi-faceted. This is because of the mutual influence of risk factors on each other. For example, the development of designer's social skills influences very strongly ${ }^{6}$ and positively ${ }^{7}$ on processes of acquiring knowledge from customers. In turn, a knowledge acquisition affects quite strongly and positively processes of building a brand of the company and increasing designer's knowledge and experience. It is interesting that this increase in knowledge and experience influences strongly and negatively on processes of knowledge sharing with customers. It is also worth to add that computerization of contacts with customers weakens processes of acquiring knowledge from them. This initial analysis of dependences from the cognitive map shows how risk management processes should be shaped, e.g. in which processes risk should be transferred which (and why) risk factors should be eliminated, and

The research has a confidential nature, and the owners do not give a permission to publish the name under which the organization operates.

6 A thickness of a vector (an arrow) specifies a strength of an impact - an vector is thicker, an impact is stronger (Fig. 3).

A positive impact is marked by a symbol “+” and negative impact by a symbol “-” (Fig. 3). 
which should be left because their impact on other processes can be beneficial (despite the fact that in certain processes generate a threat).

Obviously, discussed remarks are appropriate only to interviewed organization and cannot be generalized. They are, however, useful to draw attention to particular way to carry out a holistic risk management and to identify a little obvious (or in general non obvious) factors and dependencies. An interesting example presented in figure 3 is that in an interviewed organization a knowledge sharing with customers affects strongly and negatively processes of increasing a level of competitiveness of this organization and establishing lasting relationships with customers. This kind of situation may at first surprise manager. If I share knowledge with customers, why do I have problems with creating permanent relationships with them? There occurs a trust in this process, doesn't it? Unfortunately, this usually is not a true statement in a creative sector. In this case, there must be taken into account the factors of creativity and experience of project's author, dedicated nature of a project (for a specific customer and not to a general public) and decisional freedom of a customer. A customer, if acquires knowledge from a designer (e.g. in frameworks of possible project concepts, design principles, etc.), in the situation when price is too high, the customer looks for a new contractor / designer and convey a concept prepared by a previous designer. This process can be described as a "casting" on project's implementation in which a customer basically does not incur any costs.

It should also be underlined the fact that a cognitive map can be used to create specific "dynamic images of an organization" - a map is evolving over time, mainly by changing a strength and direction of individual dependencies, emergence of new interactions and disappearance of current ones (Godlewska-Majkowska, 2014, p. 47). This can be crucial information for those who are responsible for risk management in the organization, especially in a creative sector, which is characterized by a high level of competition and dynamics of changes, determined e.g. by trends in fashion. In addition, a cognitive map - what can be noticed thanks to analyzing dependences in figure 3 - contains elements assigned to different layers of an organization's environment, e.g. customers, a grey market, a legislation on taxes, employees' competencies, etc. 


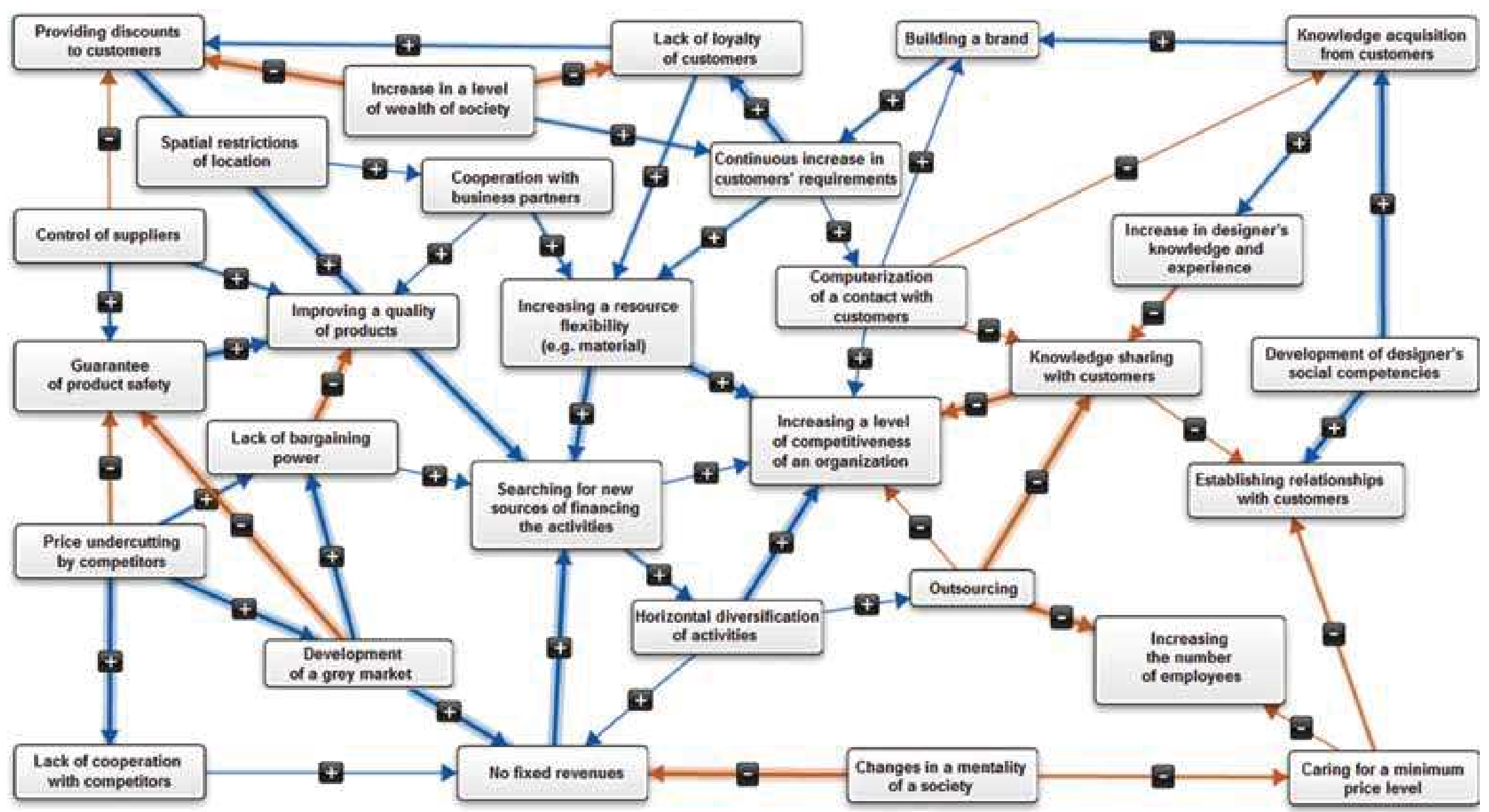

Fig. 3. A cognitive map for the issue of increasing a level of competitiveness of a creative sector organization - as an illustration of a holistic approach to identification of risk factors and dependencies between these factors

Source: own work with the use of Mental Modeler application 


\section{Summary}

Risk management in creative sector organizations is the multi-faceted and complex process. Functioning, for example, under conditions of high environment's dynamics and low structuration of decision-making situations results in a need to change an approach to interpret the risks category and implement risk management processes. One of solutions is a holistic thinking and acting which is used to identify cause and effect relationships. Thus, an organization on the one hand can record risk factors (opportunities and threats) in a relatively complete way and on the other hand - see relationships between these factors. A holistic approach offers a starting point to analyze not only direct dependencies but also indirect ones between risk factors. Therefore, a specific "decision-making picture" in an organization becomes wider, and taken decisions are charged by a lower risk of making mistakes (which does not mean that risk is completely reduced). Risk planning and control processes are "sealed". In addition, implemented and developed pattern of a business model plays a crucial role in the holistic risk management in creative sector organizations. It gives grounds to identify and connect with each other key risk factors, giving these factors an appropriate rank and placing them in a long-term development model of the entire organization.

\section{BIBLIOGRAPHY}

[1] Axelrod R., 1976, The Structure of Decision: Cognitive Maps of Political Elites, Princeton, Princeton University Press.

[2] Bharathy G.K., McShane M.K., 2014, Applying a Systems to Enterprise Risk Management, "Engineering Management Journal", vol. 26, No. 4, December.

[3] Borodzicz E.P., 2005, Risk, Crisis \& Security Management, John Wiley \& Sons, Ltd., Hoboken, New Jersey.

[4] COSO, 2004, Enterprise Risk Management - Integrated Framework, The Committee of Sponsoring Organizations of the Treadway Commission.

[5] COSO, 2013, Internal Control - Integrated Framework, The Committee of Sponsoring Organizations of the Treadway Commission.

[6] DziUrski P., 2016, Modele biznesowe w przemyslach kreatywnych, „Prace Naukowe Uniwersytetu Ekonomicznego we Wrocławiu”, No. 420, titled: Strategie. Procesy i praktyki.

[7] Godlewska-Majkowska H., 2014, Mapa kognitywna jako instrument projektowania zintegrowanego produktu turystycznego gmin, „Zeszyty Naukowe Wyższej Szkoły HUMANITAS. Zarządzanie", No. 2014 (1).

[8] ISO, 2009, ISO 31000:2009(en): Risk management - Principles and guidelines.

[9] JaCKson M.C., 2006, Creative Holism: A Critical Systems Approach to Complex Problem Situations, „Systems Research and Behavioral Science”, No. 23. 
[10] Johnson M.W., Christensen C.M., Kagermann H., 2009, Jak fundamentalnie zmienić model biznesowy firmy, "Harvard Business Review", July-August.

[11] Kasiewicz S., Rogowski W., 2006, Ryzyko a wzrost wartości przedsiębiorstwa, „Kwartalnik Nauk o Przedsiębiorstwie”, No. 1.

[12] Krysiak U., Krysiak Z., 2013, Koncepcja zrównoważonego ryzyka przedsiębiorstwa i banku, „Kwartalnik Nauk o Przedsiębiorstwie”, No. 4(29).

[13] Kucı́́ski K. (ed.), 2011, Glokalizacja, Difin, Warszawa.

[14] Kuciński K. (ed.), 2014, Ryzyko lokalizacji przedsiębiorstw w Polsce, CeDeWu, Warszawa.

[15] McNally J.S., 2015, Risk. Leverage it. Control it. Win!, "Pennsylvania CPA Journal”, Winter.

[16] Mulej M. ET AL., 2004, How to restore Bertalanffian systems thinking, "Kybernetes", vol. 33, No. 1.

[17] Piekarczy A., Zimniewicz K., 2010, Myślenie sieciowe w teorii i praktyce, PWE, Warszawa.

[18] Potocan V., Mulej M., 2009, Business cybernetics - provocation number two, „Kybernetes”, vol. 38, No. 1/2.

[19] Robertson R., 1995, Glocalisation: Time-Space and Homogeniy-Heterogenity, [in:] M. Featherstone, S. Lash, R. Robertson (eds.), Global Modernities, Sage Publications, London.

[20] Rosi B., Mulej M., 2006, The dialectical network thinking - a new systems theory concerned with management, „Kybernetes”, vol. 35, No. 7/8.

[21] Sienkiewicz P., 1988, Poszukiwanie Golema, Krajowa Agencja Wydawnicza, Warszawa.

[22] Yastrebov A., SŁoń G., 2011, Optimization and Adaptation of Dynamic Models of Fuzzy Relational Cognitive Maps, [in:] S. Kuznetsov, D. Slezak, D.H. Hepting, B. Mirkin (eds.), Rough Sets, Fuzzy Sets, Data Mining and Granular Computing - 13th International Conference, RSFDGrC 2011, Springer, Moscow.

[23] ZAsкórski P., 2012, Asymetria informacyjna w zarzadzaniu procesami, Wojskowa Akademia Techniczna, Warszawa.

[24] ZAsKórski P., 2014, Współczesna organizacja jako system $w$ systemie i nad systemem, [in:] K. Piotrkowski, Z. Wojciechowski (eds.), Uniwersalność versus różnorodność $w$ teorii i praktyce zarzadzania, Military University of Technology, Warszawa.

\section{Internet Sources:}

[1] Grochowsкi M. ET AL., 2012, Sektor kreatywny w województwach pomorskim i kujawsko-pomorskim, Gdańsk, https://kreatywni.arp.gda.pl/plik,54,raport-skb-2012-pdf.pdf [25.06.2016].

[2] Pasamonik B., 2016, Globalizacja kultury czy glokalizacja kultur?, http://www.academia. edu/16235663/Globalizacja_kultury_czy_glokalizacja_kultur [10.08.2016]. 